\title{
Contribution to an Anaerobic Digester Heating using Solar Energy, under Cotonou Temperature Conditions
}

\author{
Cessac Franck Clair HOUNGUE \\ Laboratory of Electrotechnic Telecommunications and Applied Informatics \\ Polytechnic school of Abomey-Calavi, Calavi, Benin \\ Kokou Théophile HOUNGAN \\ Laboratory of Electrotechnic Telecommunications and Applied Informatics \\ Polytechnic school of Abomey-Calavi, Calavi, Benin \\ Edmond Codjo ADJOVI \\ Department of Civil Engineering \\ Polytechnic school of Abomey-Calavi, Calavi, Benin
}

\begin{abstract}
This work is about the survey of an anaerobic batch digester heated with solar rays. Only heating by solar rays is considered in this work. There is no backup heating. The heating system is a parabolic solar concentrator. It is provided with a regulator that is set to keep the substrate temperature within a specific range $\left(35^{\circ} \mathrm{C}\right.$ to $\left.38^{\circ} \mathrm{C}\right)$. This enables a greater methane production in a short time. This work was done, under Cotonou city conditions in Benin Country. We use Hardware In the Loop simulation (HILS) to appreciate the performance of the regulation device. The heating permitted the reduction of digestion time which dropped from 30 days to 15 days.
\end{abstract}

Keywords - Anaerobic digestion, Solar heating, Cotonou city temperature conditions, Hardware in the Loop

\section{INTRODUCTION}

One of the challenges that the scientists are facing, is the energy issue. In such a context, news technologies of energy are motor of innovation [1]. Renewable energies are placed in pole position of these new energy technologies and are increasingly stretched. Among these renewable energies, anaerobic digestion remains a renewable source of energy that is more accessible to people, especially rural communities.

Anaerobic produces biogas (mainly formed of: $50 \%$ to $70 \%$ methane for $30 \%$ to $50 \% \mathrm{CO}_{2}$ ) by the degradation of organic matter in the absence of oxygen and under the effect of microorganisms. This transformation of organic matter into methane is done in several steps (hydrolysis, acid formation, acetone formation and methane formation).

The methane formation process is done over several days. Its duration, in the case the process evolves in natural conditions, is dependent on the mass, the type and the dry matter content of the material to digest. For instance, 130L of organic matter may last one month[2].The methane formation duration is linked to many factors including $\mathrm{pH}$, alkalinity, and temperature[3]. Furthermore, it is known that raising the temperature in the digester, could increase the growth rate of methanogenic bacteria, and therefore increase the kinetics of methane production [4]. In Benin country, anaerobic digestion starts to develop. But the monthly average level of daily irradiations are $3.9 \mathrm{kWh} / \mathrm{m}^{2}$ to $6.2 \mathrm{kWh} / \mathrm{m}^{2}$ and the sunshine duration is 4.5 to 6 hours by day[5].

Then this work focuses on regulating under the temperature of a batch digester, heated by a parabolic solar concentrator. It was carried out using a simulation based on the concept of Hardware In the Loop Simulation (HILS).

\section{MATERIALS AND METHODS}

\section{A. The Digester}

The considered digester is a batch type. It is a closed tank used for the degradation of the organic matter. As shown at figure 1, a hot water line is installed inside the digester for heating the substrate. There is a parabolic solar ray concentrator which heats the water inside the hot water line in the digester through an opening covered by a glass. The water line in the digester is realized with an iron plate. The outer part is covered by a thermic insulator. 


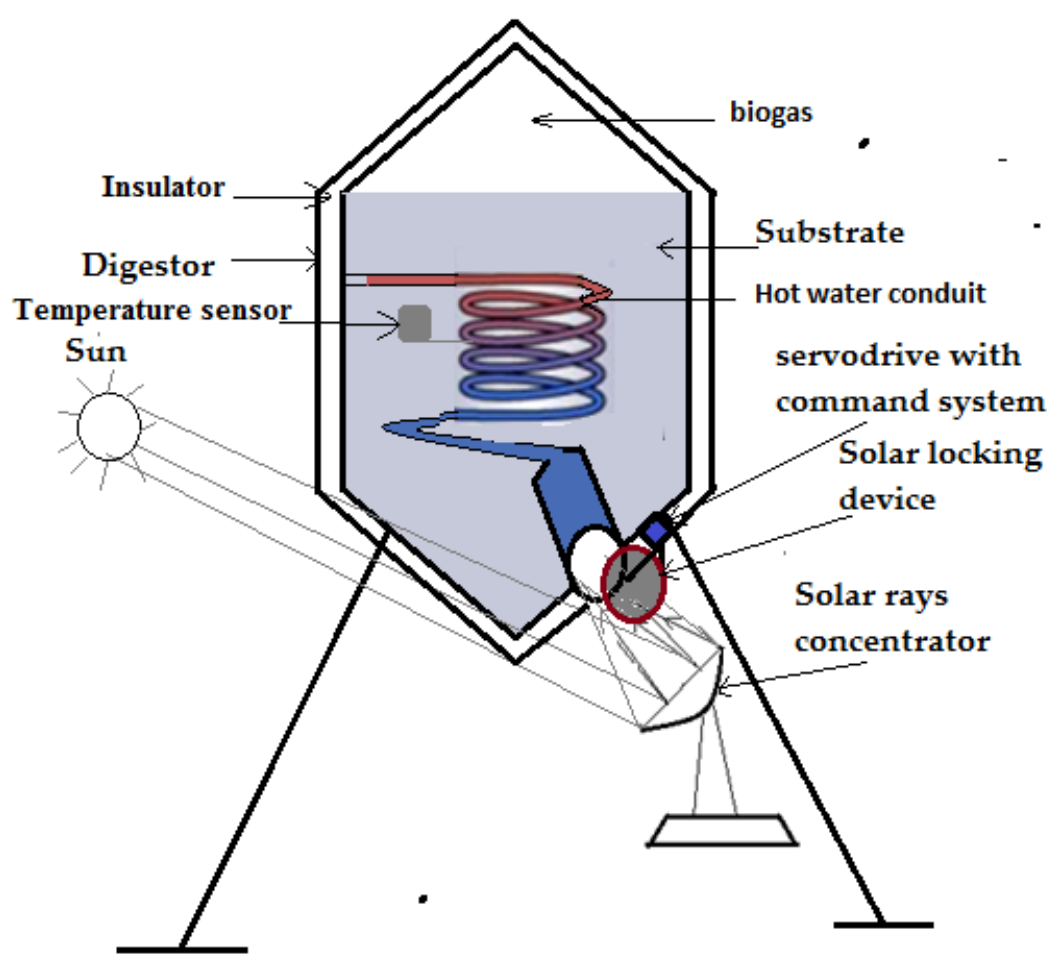

Figure 1. Digester description

\section{B. Solar heating of digester}

Digester heating is a technique to ensure the temperature range necessary for the proliferation and activity of bacteria. Generally, anaerobic digestion takes place in three temperature ranges: a temperature " $\mathrm{T}$ » less than $20^{\circ} \mathrm{C}$ $\left(\mathrm{T}<20^{\circ} \mathrm{C}\right.$ ) that is called psychrophilic digestion, $\left(20<\mathrm{T}<44^{\circ} \mathrm{C}\right)$ for mesophilic digestion system and thermophilic digestion which takes place at temperatures above $44^{\circ} \mathrm{C}\left(\mathrm{T}>44^{\circ} \mathrm{C}\right)[6]$.

If in temperate climate zones and industrial environment, heating the digesters system is a common use, in hot climate zone and developing countries like Benin, most digesters are family setting and do not benefit from the heating system. This because of the air temperature that is more or less hot; the annual average temperature of Benin country is between $26^{\circ} \mathrm{C}$ and $28^{\circ} \mathrm{C}$ [7]; there is lack of profitability of reuse of biogas to heat the digester since these are small-scale installations. Besides the main objective by heating the digester in our case is to allow the degradation of a larger quantity of waste; which has a strong positive impact on environmental sanitation. The solar heating issue has been addressed by some authors. Thus, a solar heating system using a plan solar collector covering the top of the digester was tested by Hadri et al. [8]. Also, the use of a conventional solar water heater has been proposed by Yettou et al. [9]. This work investigates the use of a heating system based on a parabolic solar concentrator.

\section{Hardware in the loop simulation}

Hardware In the Loop Simulation (HILS) is a technique linking classical simulation and test on a physical device. It is strictly linked to real time simulation ( Hanselmann 1993; Isermann et al. 1999; Kiffmeier 1996; Lu et al. 2007). The HILS includes a mathematical model of the process and a hardware device such as electronic control unit (ECU) we want to test, e.g. an industrial PID controller. The hardware device is normally an embedded system. To perform HILS of a process P, we divide it into two parts. One will be simulated; we will note it (S) (This is often the operative part of the process under study) and the other is kept physical; it will be noted (R) (It may be the control/command system of the process). Then the model of (S) is carried out in a computer for simulation. (R) is kept as such. It is made a communication interface between (R) and (S). Thus, the physical part (R) and the simulated part (S) communicate in a closed loop in real time through the interface [11], [14]. The advantage of HILS is that we are much closer to the actual behavior of the process because all the process is not simulated. This 
increases the realism of the simulation [11]. Moreover, that type of simulation allows the easy use and reuse of the model lodged on the computer, it also avoid carrying a loss of material and life in some cases.

HILS was chosen to carry out this work. Indeed, we needed to make several tests to determine the heating temperature to be applied, the time required for heating and the time the substrate takes to cool so that we can efficiently size the equipment of the heating system. Performing, all these tests on the physical digester require not only much time but also to be able to set a certain initial size of heating equipment. Simulation is a good way to get the dimensions moreover for sizing the heating system. Furthermore, the HILS more than conventional simulation enables to be closer to reality since the control part of the heating system would have already been made and used physically for this simulation.

In our case, to perform the calculations of temperature control within the digester in order to control the actuator, it was used the Arduino UNO board. The simulation software used is LabVIEW. It is host of the mathematical model of the simulated part. The model of the digester used, is a two-step model(Antonelli et al. 2003; Bernard et al. 2001; Grognard \& Bernard 2006; Hess \& Bernard 2008; Mailleret et al. 2003) . It was originally developed by INRIA (Institut National de Recherche en Informatique et en Automatique) of Narbonne in France. It reflects changes in acid formation and methane formation where the substrate $S_{1}$ is degraded to $S_{2}$. In fact, carbon matters in $S_{1}$ are transformed into volatile fat acids $\left(S_{2}\right)$ by bacteria $X_{1}$, and $S_{2}$ is degraded by bacteria $X_{2}$ into methane and into dioxide carbon. The two steps model equations for batch digester are: [2]

$\dot{S}_{1}=-k_{1} \times \mu_{1}\left(S_{1}\right) \times X_{1}$

(1)

$\dot{X}_{1}=\mu_{1}\left(S_{1}\right) \times X_{1}$

(2)

$\dot{S}_{2}=k_{2} \times \mu_{1}\left(S_{1}\right) \times X_{1}-k_{3} \times \mu_{2}\left(S_{2}\right) \times X_{2}$

$\dot{X}_{2}=\mu_{2}\left(S_{2}\right) \times X_{2}$

$X_{1}$ and $X_{2}$ are respectively the concentration of the acidogenic and methanogenic bacterial population;

$S_{1}$ and $S_{2}$, are respectively the initial substrate concentration (carbonated matter) and the concentration of volatile fat acids (resulting of the first degradation realized by acidogenic bacteria).

$k_{i}$ are the pseudo-stoichiometric coefficients associated with the two reactions.

The flow of methane, which is the expected product, directly depends on the growth of methanogenic bacteria population $X_{2}$, according to the relationship:

$Q_{\mathrm{CH}_{4}}=k_{4} \mu_{2}\left(S_{2}\right) X_{2}$

$\mu_{1}, \mu_{2}$ represent the growth kinetics respectively of acidogenic and methanogenic bacteria.

$\mu_{1}$, follows the kinetics of Monod, while ${ }^{\mu_{2}}$ following the kinetics of Haldane:

$\mu_{1}\left(S_{1}\right)=\frac{\mu_{1 \max } s_{1}}{K_{S 1}+s_{1}}$

$\mu_{2}\left(S_{2}\right)=\frac{\mu_{2 \max } S_{2}}{K_{S 2}+S_{2}+\frac{s_{2}^{2}}{K_{i}}}$

$\mu_{1 \max }$ and $\mu_{2 \max }$, represent the maximum growth rate during respectively the acidogenic phase and the methanogenic phase.

\section{Using the Ratkowsky formula to access the substrate temperature}

Most studies that have been done on modeling the digestion process were made at constant temperature[20]-[23]. In our case, the temperature will not be constant since the objective is to maintain it within a certain range ( $35^{\circ} \mathrm{C}$ to $38^{\circ} \mathrm{C}$ ), it is necessary to take into account the evolution of the temperature in the digester. This is moreover, a decisive factor for the starting or stopping point of heating.

Thus, in order to access to the temperature in the mathematical model, we used Ratkowsky formula which gives the bacterial growth rate as a function of temperature [24]:

$$
\sqrt{\mu}=b\left(T-T_{\min }\right)
$$


Where b is a regression coefficient, ${ }^{T}$ the temperature of the medium and $T_{\min }$ is the minimum temperature below which there is no growth [24], [25]. We replaced in Monod and Haldane formulas, the maximum growth rate $\mu_{1 \max }$ and $\mu_{2 \max }$ by the previous as written in Ratkowsky formula. This alternative is justified as follows: According to Zwietering et al., [26] we have:

$\mu_{\max }=\mu_{o p t} \prod_{i=1}^{n} \gamma\left(f_{i}\right)$

Where $f_{i}$ are the environmental factors that influence the process such as temperature, moisture content, $\mathrm{pH}$, etc...

$\gamma\left(f_{i}\right)=\frac{\mu\left(f_{i}\right)}{\mu_{\text {opt }}}$.

In the case of this study, taking into account the external influence factor that is temperature, we obtain:

$\mu_{\max }=\mu_{\text {opt }} \gamma(T)$

Therefore:

$\mu_{\max }=\mu_{\text {opt }} \cdot \frac{\mu(T)}{\mu_{\text {opt }}}=\mu(T)$

The maximum growth rates are assessed as followed:

$\sqrt{\mu_{1 \max }}=\mathrm{b}_{1}\left(\mathrm{~T}-\mathrm{T}_{\min }\right)$

$\sqrt{\mu_{2 \max }}=\mathrm{b}_{2}\left(\mathrm{~T}-\mathrm{T}_{\min }\right)$

Modeling the evolution of the temperature in the digester

To model the temperature of the substrate, we considered by assumption that:

- The temperature of the glass, substrate and the iron plate are uniform;

- The substrate is assimilated to water.

- The metal outer side of the pipe which is inside the digester is considered as part of the substrate.

E. Thermic balance( Duffie \& Beckman 2013; Holman 2009; Kwatra 1996)

From these assumptions, an energy balance has been established at each element taken separately:

2.4.1 The glass

$h r_{p-v} A_{0}\left(T_{p}-T_{v}\right)+h c_{p-v} A_{0}\left(T_{p}-T_{v}\right)=h r_{v-c i e l} A_{0}\left(T_{v}-T_{e}\right)+h c_{v-a} A_{0}\left(T_{v}-T_{p}\right)$

where $t_{c}=0.052\left(t_{a}\right)^{1,5}$

With $A_{0}$, surface of the water line; $T_{p}$ temperature of the water line; $T_{v}$ temperature of the glass; $T_{c}$ Temperature of the sky; $h r_{p-v}$ radiative exchange coefficient between the iron line and the glass; $h c_{p-v}$ convective exchange coefficient between the iron line and the glass; $h r_{v \text {-ciel }}$ radiative exchange coefficient between the glass and the air; $h c_{v-a}$ : convective exchange coefficient between the glass and the atmosphere;

2.4.2 The iron plate (hot water line)

$$
\begin{gathered}
\tau_{v} \cdot \alpha_{p} \cdot G \cdot A_{0}=h r_{p-v} \cdot A_{0} \cdot\left(T_{p}-T_{v}\right)+h c_{p-v} \cdot A_{0} \cdot\left(T_{p}-T_{v}\right)+h_{p} \cdot A_{0} \cdot\left(T_{p}-T_{s u b}\right) \\
\frac{1}{h_{p}}=\frac{e}{K_{a c}}+\frac{1}{h r_{p-s u b}+h c_{p-s u b}}
\end{gathered}
$$

With $\tau_{v}$ transmissivity coefficient of the glass; ${ }^{\alpha p}$ absorption coefficient of the plate; Solar irradiance $G ; T_{s u b}$ : substrate temperature; $^{e}$ thickness of the iron plate; $K_{a c}$ coefficient of thermal conductivity of the iron plate; $h r_{p-s u b}$ : radiative exchange coefficient between the iron plate and the substrate; $h c_{p-s u b}$ : convective heat exchange coefficient between the iron plate and the substrate; ${ }^{h}$ : global loss coefficient.

2.4.3 The substrate

$M_{s u b} \cdot C_{p} \cdot \frac{d T_{s w b}}{d t}=h_{p} \cdot A_{0} \cdot\left(T_{p}-T_{s u b}\right)-h_{\text {perte }} \cdot A_{0} \cdot\left(T_{s u b}-T_{a}\right)$ 


$$
h_{\text {perte }}=\frac{K_{\text {is }}}{\theta_{i s}}+\frac{K_{i s} * S_{1}}{\theta_{i s} * A_{0}}
$$

With $M_{\text {sub }}$ : substrate weight; $C_{p}$ calorific capacity of water; $h_{\text {perte }}$ global loss coefficient of the substrate; $K_{i s}$ coefficient of thermic conductivity of the insulator; $e_{i s}$ thickness of the insulator; $\mathrm{S}_{1}$ lateral surface of the iron pipe which is in contact with the substrate.

This model enables to know the variation of the temperature inside the digester.

The parabolic solar concentrator is installed as shown in Figure 1 with rays concentrated at the parabola focus coinciding with the hole covered by a glass. At the entrance to this hole, is a locking system whose operation is controlled by an actuator. The solar concentrator is linked to a solar tracker that enables the system benefiting from the sunshine throughout the day. The solar tracker study is not part of this work.

A temperature sensor is installed in the digester to provide information on the temperature within it. When the temperature is below a defined threshold, the temperature sensor signals this to a programmed control unit, which will command the opening action of the locking system through the actuator. Once the locking system is opened the heating starts and continuously until it is detected that the maximum temperature admitted to the digester is reached. The locking system then closes to stop the heating.

The actuator and the parabolic concentrator were modeled by a program. That program receives as input the voltage supplied to the actuator which is generated by the control unit and delivers the heating temperature of the digester: ambient temperature or temperature imposed by the concentrator of sunlight. Figure 2 shows a schematic of the system to study into two parts that are: the part to be simulated and the control unit that will be physical. The control unit is represented by the regulator made from an ARDUINO UNO board. Part to be simulated is represented by the models of actuator, concentrator and digester which are set and lodged inside a computer. The connection between the two sides is realized through USB port. The simulation software is the LabVIEW 2013. The temperatures used are recorded data at the meteorological station of Cotonou-Airport from 1 February to 2 March 2015.

A complete explication on USB port data acquisition in LabVIEW is provided in [30], [31].

Figure 3 and figure 4 present respectively the digester model realized in LabVIEW and the communication block implemented in LabVIEW for data transmission between the ARDUINO UNO board and the digester model.

\section{Control unit}

(Physical part)

Simulated part (lodged in the computer)

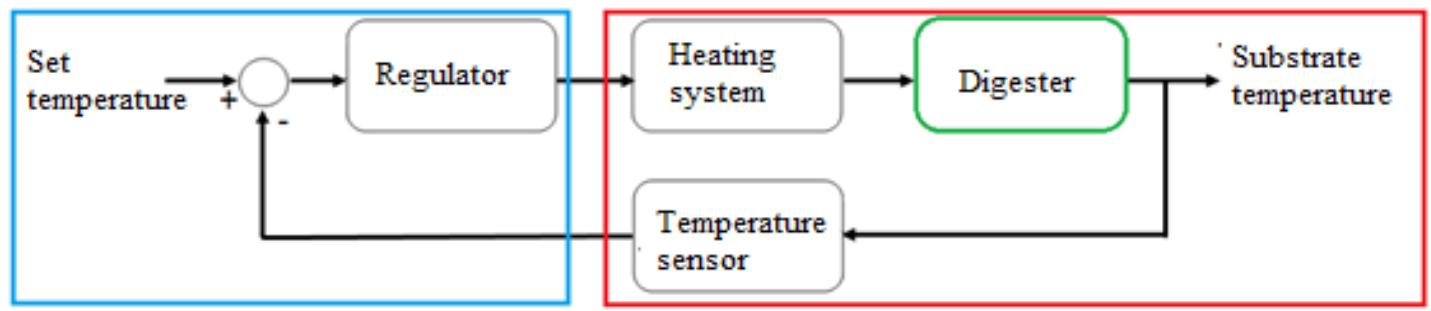

Figure 2. Separation into two parts of the system under study

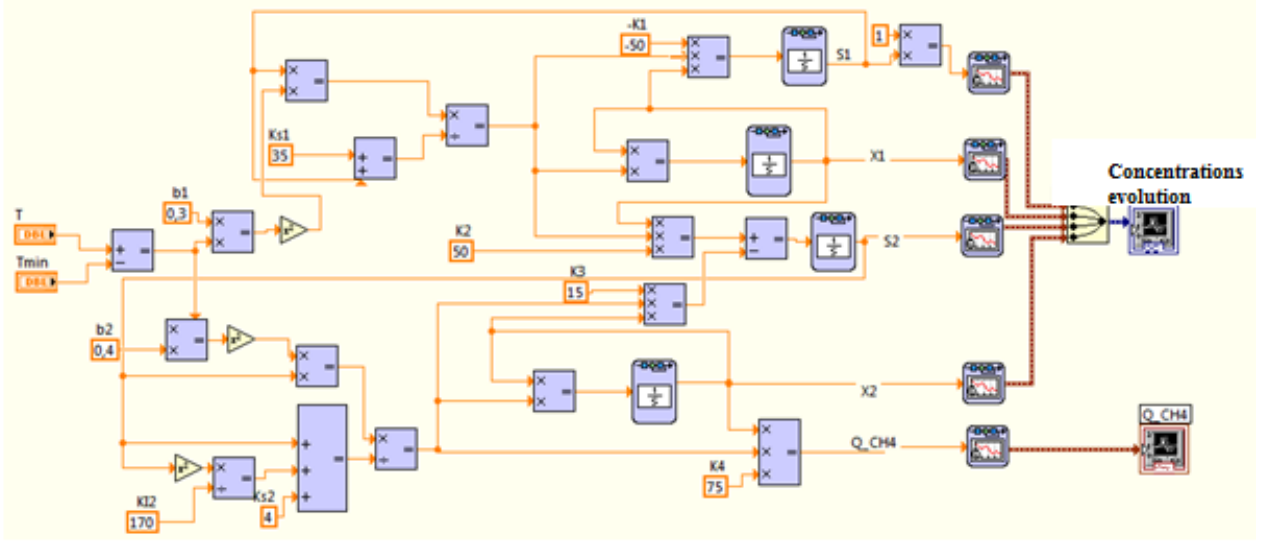


Figure 3. Implementation of the model of the anaerobic digestion process

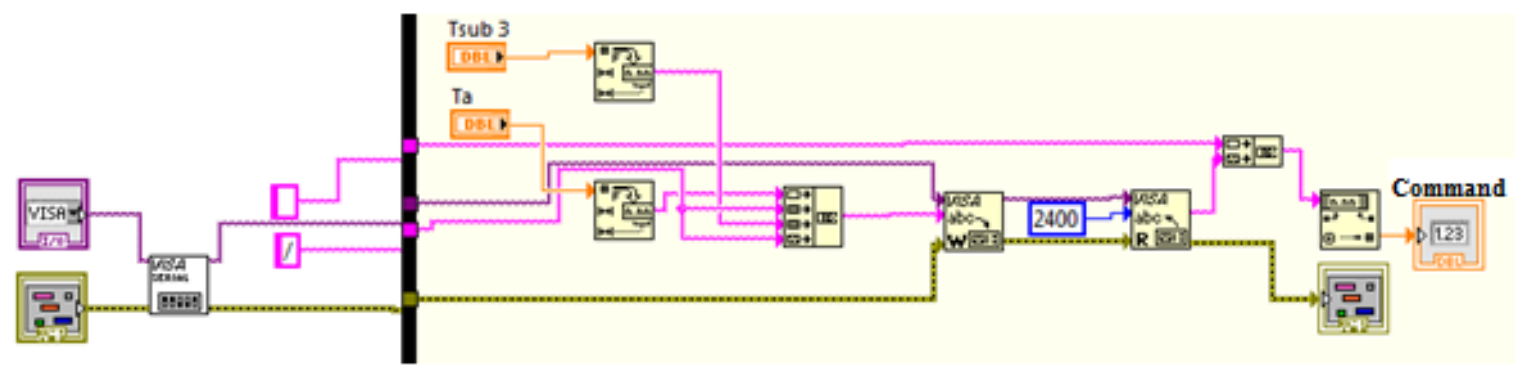

Figure 4. Block of Transmission and Reception of Data implemented in LabVIEW

\section{RESULTS AND DISCUSSION}

We present firstly the evolution of the substrate temperature. In second time, we present the evolution of nutrients concentration and methane production. The beginning instant of the simulation corresponds to midnight (0 hour).

Figure 5 shows the evolution of the substrate temperature without heating. We can observe that the process lasts 30 days in that case. But when the digester was heated, the process duration was divided into two and was 15 days (figure 11). As we use solar rays to heat the digester, it is not possible to maintain the heating during the night. Then figure 6.f shows that the substrate temperature decreases regularly on night and it is only by day, when solar rays are available, that the substrate temperature increases.

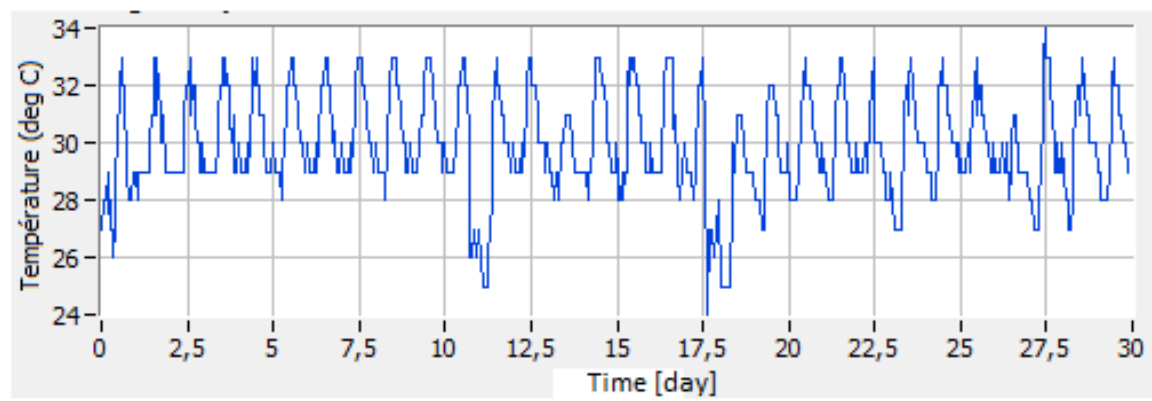

Figure 5. Substrate temperature when digester is under ambient temperature (150kg of organic waste) 

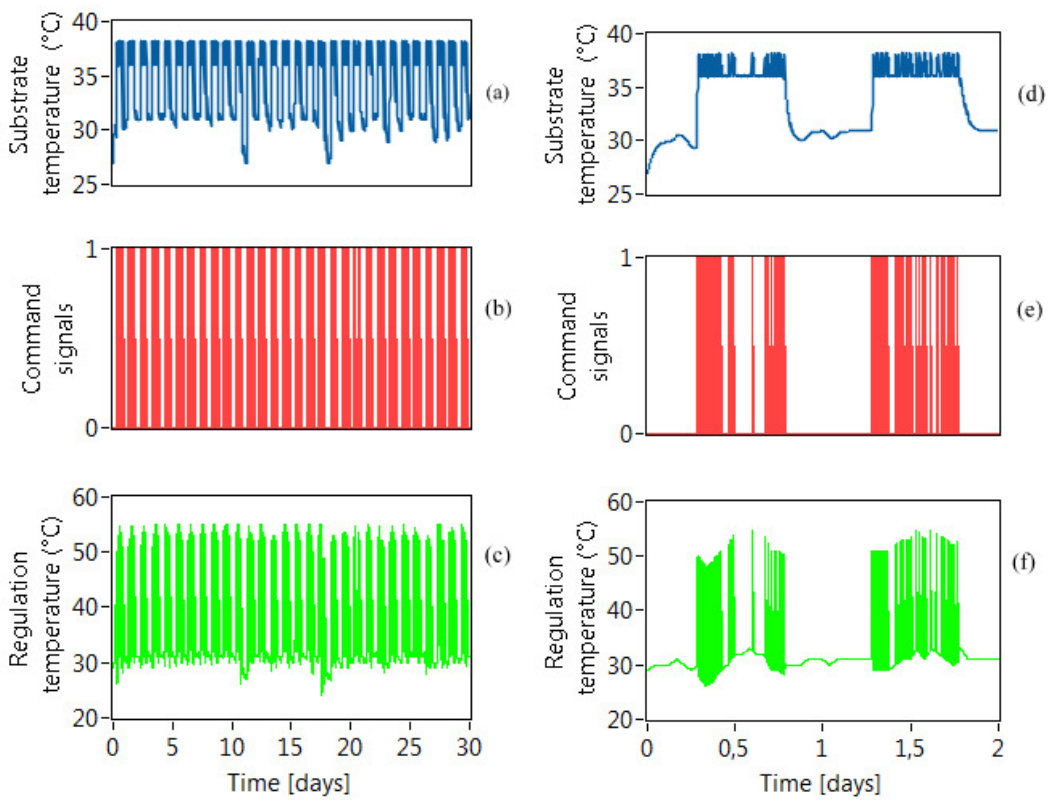

Figure 6. Obtained performances with heating; 150kg of organic waste.

We can note that, under ambient temperature, the substrate temperature is between $24^{\circ} \mathrm{C}$ and $33^{\circ} \mathrm{C}$. It is the kind of profile which is expected for a batch digester. [32] presents similar results for substrate temperature in batch digester. When heating is used, for the $150 \mathrm{~kg}$ of organic waste, the substrate temperature is contained between $31^{\circ} \mathrm{C}$ and $37^{\circ} \mathrm{C}$; but sometimes it reaches $26^{\circ} \mathrm{C}$. Those moments correspond to the lowers temperatures of the night. We observe them on the $11^{\text {th }}$ day and the $17^{\text {th }}$ day. Then, with the first solar rays, which appear at about $6 \mathrm{~h} 43 \mathrm{~min}$, the substrate temperature quickly increases and attains $38^{\circ} \mathrm{C}$ at $7 \mathrm{~h} 11 \mathrm{~min}$ and the heating system is disconnected. We have 28 minutes of heating. But substrate temperature shows a fast decrease and after 15 minutes, it arrives at $35^{\circ} \mathrm{C}$ and the heating begins again. This is due to the small quantity of organic waste in the digester. Thus the heating system will be frequently sought. Then in the same operations conditions, we increase the organic waste quantity in the digester. The results are presented at figure 7 and figure 8.

When heating the digester with $3000 \mathrm{~kg}$ of organic waste inside, the substrate temperature is contained between $33^{\circ} \mathrm{C}$ and $38^{\circ} \mathrm{C}$; but sometimes it decreases to $30.65^{\circ} \mathrm{C}$. Those moments too, correspond to the lowers temperatures of the night. But by days, when solar rays are available, the substrate temperature is strictly contained between $35^{\circ} \mathrm{C}$ and $38^{\circ} \mathrm{C}$ as the control unite set it. Here, with the first solar rays of the first day, the heating begins and last 403 minutes. The highest temperature permitted for the substrate $\left(38^{\circ} \mathrm{C}\right)$, is achieved after 403 minutes of heating. The heating system was requested twice each day. The greater temperature shock we have is $6.35^{\circ} \mathrm{C}$. That temperature shock occurs on $17^{\text {th }}$ day, by night. It corresponds to the lowest external temperature of the experimentation period. According to [33], that value of temperature shock can be tolerate. [34] Proves that in mesophilic digester, the bacteria are able to adapt to higher temperature after a few days. Nevertheless it is better to avoid temperature shock in a digester; as we noted that with increasing the organic waste quantity in the digester help to reduce shock value, we studied the behavior of the substrate temperature when we have $10000 \mathrm{~kg}$ of organic waste. The results are on figure 8.

When we have $10000 \mathrm{~kg}$ of organic waste, the substrate temperature is maintained between $35^{\circ} \mathrm{C}$ and $38^{\circ} \mathrm{C}$ with two descents to $34^{\circ} \mathrm{C}$. The substrate temperature reached with difficulty the $38^{\circ} \mathrm{C}$. We needed to wait for the second day end before obtain $38^{\circ} \mathrm{C}$. But when temperature reaches $38^{\circ} \mathrm{C}$, due to the high quantity of organic waste inside the digester, it does not decrease quickly. That appears as an advantage which enables avoid great temperature shock. Moreover, the heating system is requested once per day during the experimentation time.

Now we present on figure 9, figure 10 and figure 11, figure 12 respectively, the evolution of nutrients concentration, and the methane production when the process is without heating and with heating. The used quantity of waste is $150 \mathrm{~kg}$. 

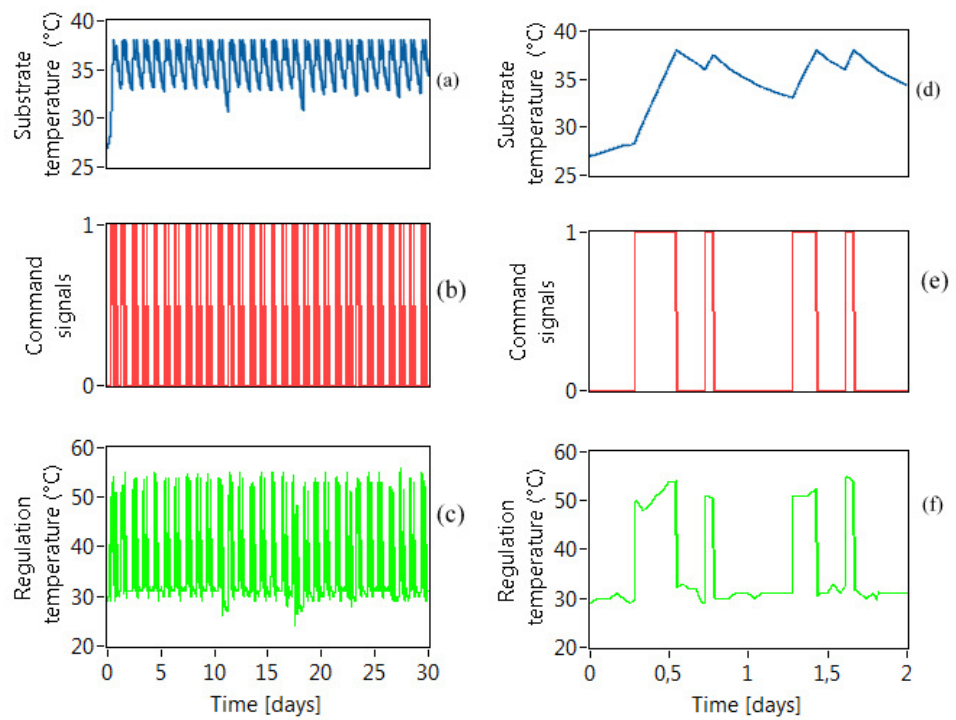

Figure 7. Obtained performances with heating; 3000kg of organic waste
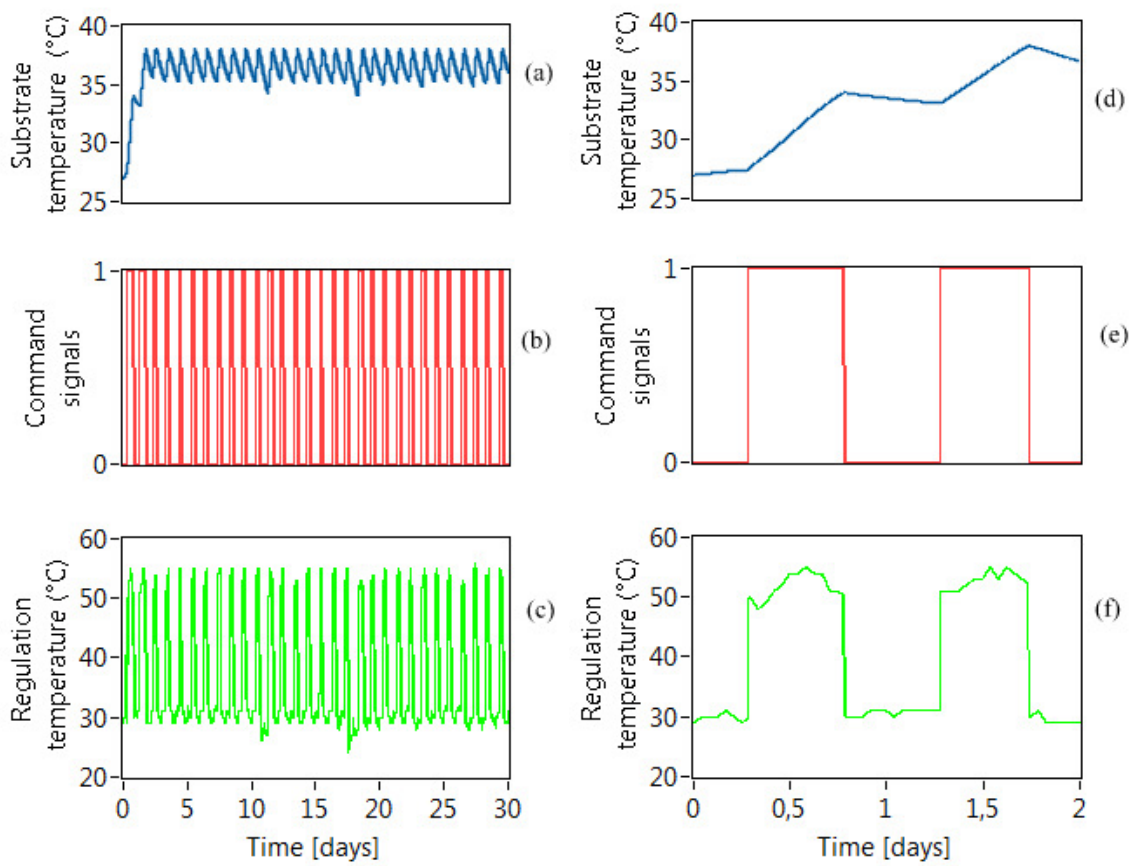

Figure 8. Obtained performances with heating; $10000 \mathrm{~kg}$ of organic waste 

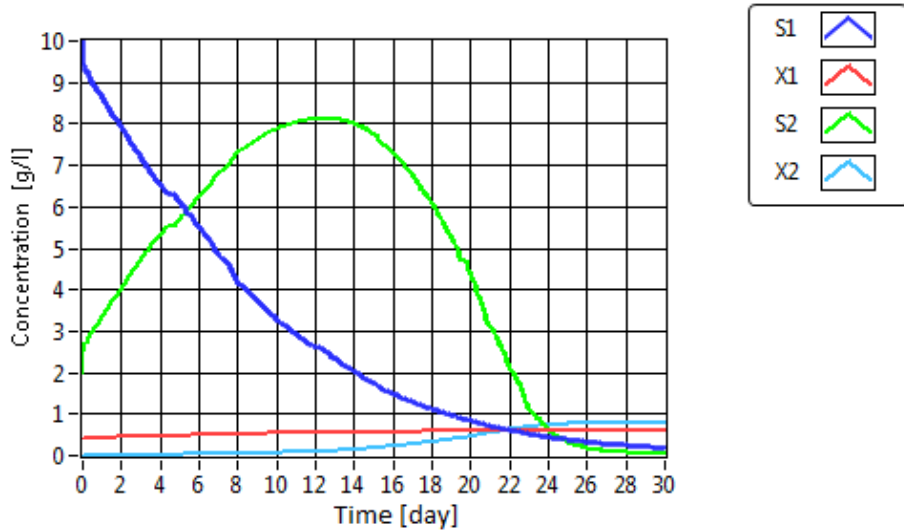

Figure 9. Evolution of concentrations of nutrients (Without heating). S1: initial substrate; X1: acidogenic bacteria; S2: Volatile fats acids; X2: Methanogenic bacteria; $150 \mathrm{~kg}$ of organic waste.
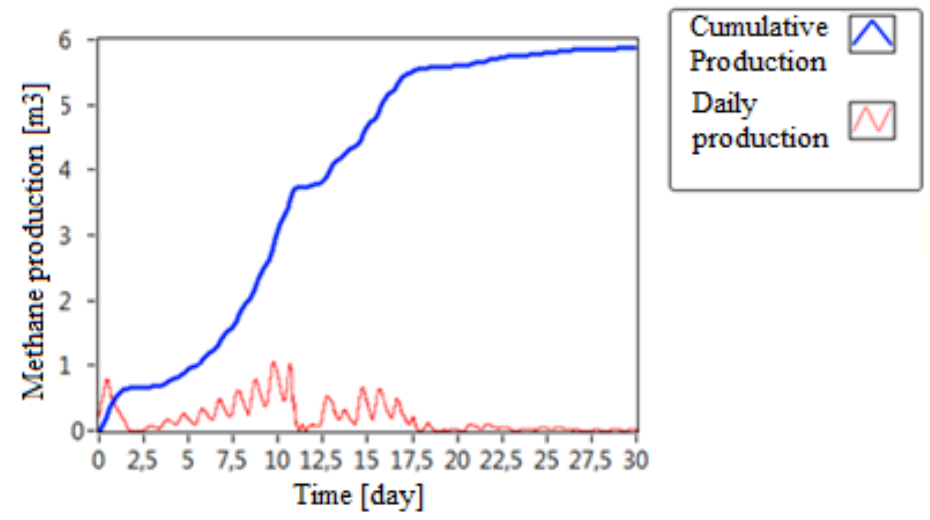

Figure 10. Methane production; Without heating; 150kg of organic waste.
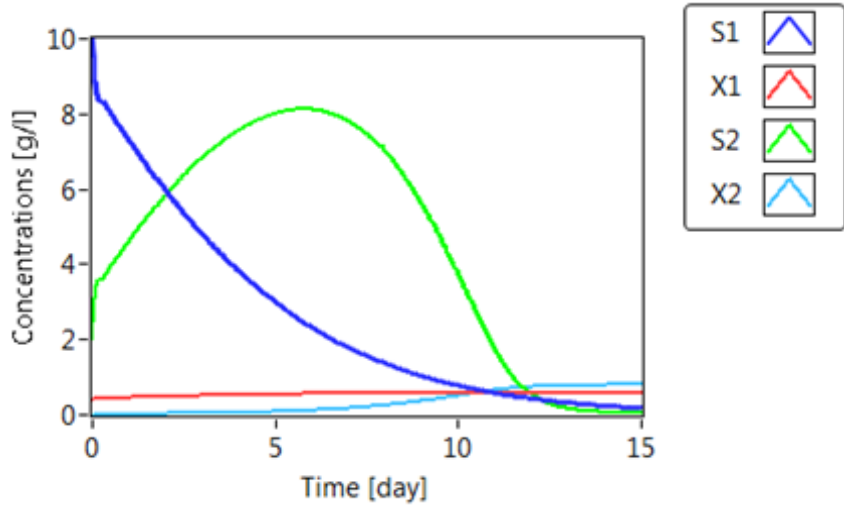

Figure 11. Evolution of nutrients concentrations; with heating; 150kg of organic waste. S1: initial substrate; X1: acidogenic bacteria; S2: Volatile fats acids; X2: Methanogenic bacteria. 

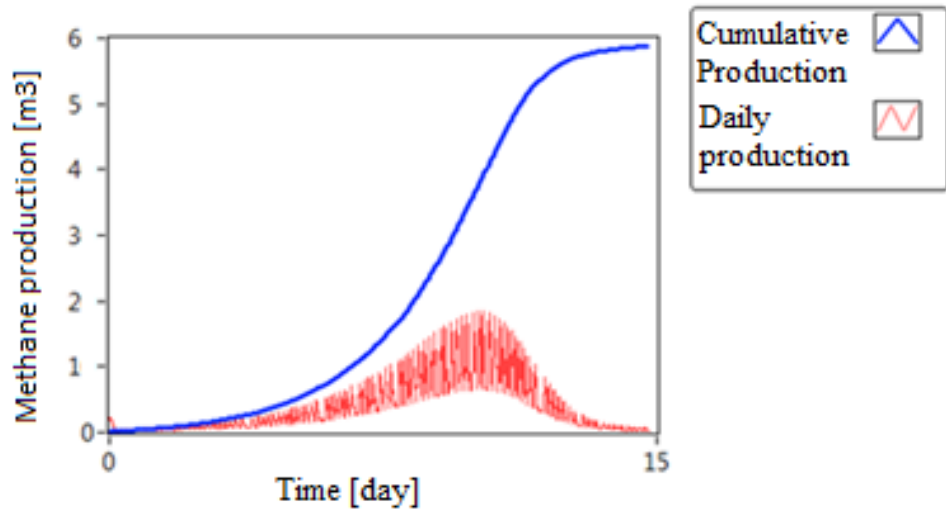

Figure 12. Methane production; With heating; 150kg of organic waste.

Concerning the biogas production, we obtain $6 \mathrm{~m}^{3}$ of bio-methane for $150 \mathrm{~kg}$ of organic waste. This is similar to the results presented in [35]. We can observe that the process duration was divided into two. It is very interesting because this allows the treatment of a higher quantity of waste by the small scale digester in rural area.

\section{IV.CONCLUSION}

The observation of the different results shows that the overall operation that was obtained, is the one expected for a batch digester. After a comparative analysis of performance of the different simulated systems, several conclusions may be drawn. The anaerobic digestion process is faster when the substrate temperature is controlled (maintained in the range of $35^{\circ} \mathrm{C}$ to $38^{\circ} \mathrm{C}$ ). Heating by solar concentration system has reduced the methane producing time. But using only solar rays without backup heating have a weakness: the temperature of the organic waste drops much by night before increase the following days. If it is true that a large quantity of organic waste help to avoid fast decrease of temperature inside the digester, it would be interesting to have backup thermic energy to ensure heating by night. In another hand, HILS enabled limiting a number of simulation hypothesis, taking into account the actual characteristics of the control board, what gives more exact outcomes. In other words, with the HILS, the regulation is not ideal, but a little bit more real. However, it would be very interesting to verify the actual performance of the digester in normal operating position in order to confirm the results. This is a prospect work.

\section{REFERENCES}

[1] F. Romerio, Les controverses de l'énergie: fossile, hydroélectrique, nucléaire, renouvelable. 2008.

[2] A. Zaatri, N. Kacem Chaouche, and M. Karaali, "Etude de bioréacteurs anaérobies expérimentaux pour la production de méthane,” Rev. des Energies Renouvelables, vol. 14, pp. 291-300, 2011.

[3] R. Braun, "Anaerobic digestion: a multi-faceted process for energy, environmental management and rural development," in Improvement of Crop Plants for Industrial End Uses, Dordrecht: Springer Netherlands, 2007, pp. 335-416.

[4] P. R. Córdoba, F. S. Riera, and F. Sineriz, “Temperature effects on upflow anaerobic filter performance,” Environ. Technol. Lett., vol. 9, no. 8, pp. 769-774, Aug. 1988.

[5] A. B. YATOKPA, S. MAHMAN, and K. ABBLE, "Identification des potentialités et modalités d'exploitation des sources d'énergies renouvelables sur l'ensemble du territoire national," Cotonou, 2010.

[6] J. Lacour, "Valorisation de résidus agricoles et autres déchets organiques par digestion anaérobie en Haïti,” L’Institut National des Sciences Appliquées de Lyon (France), 2012.

[7] C. J. S. D. Gbémavo, C. P. Gnanglé, E. A. Assogbdjo, and L. R. Glèlè Kakaï, "Analyse des Perceptions Locales et de Facteurs Déterminant l'Utilisation des Organes et des Produits du Jatropha Curcas Linn. (EUPHORBIACEAE) au Bénin,” Agron. Africaine, vol. 26, no. 1, pp. 69-79, 2014.

[8] K. Hadri, M. Khelafi, A. Boulal, and N. Nedjah, "Conception et réalisation d'un digesteur solaire de type batch,” Rev. des Energies Renouvelables, vol. ICRESD-07, pp. 97-100, 2007.

[9] F. Yettou, a Gama, C. Hamouda, and a. Malek, "Etude et réalisation d'un banc d'essai pour un chauffe-eau solaire à circulation forcée dans la région des Hauts Plateaux,” Rev. des Energies Renouvelables, vol. 11, no. 1, pp. 119-128, 2008.

[10] R. Isermann, J. Schaffnit, and S. Sinsel, "Hardware-in-the-loop simulation for the design and testing of engine-control systems," Control Eng. Pract., vol. 7, no. 5, pp. 643-653, May 1999.

[11] B. Lu, X. Wu, H. Figueroa, and A. Monti, "A Low-Cost Real-Time Hardware-in-the-Loop Testing Approach of Power Electronics Controls,” IEEE Trans. Ind. Electron., vol. 54, no. 2, pp. 919-931, Apr. 2007.

[12] H. Hanselmann, "Hardware-in-the-loop simulation development and test of electronic control units and mechanical components," in The Real Time Conference, 1993.

[13] U. Kiffmeier, "A hardware-in-the-loop testbench for ABS controllers," in Conference on Control and Diagnostics in Automotive Applications, 1996.

[14] I. Munteanu, A. I. Bratcu, S. Bacha, D. Roye, and J. Guiraud, "Hardware-in-the-Loop-based Simulator for a Class of Variable-speed Wind Energy Conversion Systems: Design and Performance Assessment,” IEEE Trans. Energy Convers., vol. 25, no. 2, pp. 564-576, Jun. 2010. 
[15] R. Antonelli, J. Harmand, J.-P. Steyer, and A. Astolfi, "Set-point regulation of an anaerobic digestion process with bounded output feedback,” IEEE Trans. Control Syst. Technol., vol. 11, no. 4, pp. 495-504, Jul. 2003.

[16] F. Grognard and O. Bernard, "Stability analysis of a wastewater treatment plantwith saturated control,” Water Sci. Technol., vol. 63, no. 1, pp. 149-157, Feb. 2006.

[17] L. Mailleret, O. Bernard, and J. P. Steyer, "Robust regulation of anaerobic digestion processes.,” Water Sci. Technol., vol. 48, no. 6, pp. 87-94, Jan. 2003.

[18] O. Bernard, Z. Hadj-Sadok, D. Dochain, A. Genovesi, and J. P. Steyer, "Dynamical model development and parameter identification for an anaerobic wastewater treatment process.,” Biotechnol. Bioeng., vol. 75, no. 4, pp. 424-438, Nov. 2001.

[19] J. Hess and O. Bernard, "Design and study of a risk management criterion for an unstable anaerobic wastewater treatment process," $J$. Process Control, vol. 18, no. 1, pp. 71-79, Jan. 2008.

[20] J. E. Haag, A. Vande Wouwer, and I. Queinnec, "Macroscopic modelling and identification of an anaerobic waste treatment process," vol. 58, pp. 4307-4316, 2003.

[21] J. Mata-alvarez, F. Cecchi, P. Pavan, D. S. Ambientali, and U. Venezia, “Anaerobic Digestion of the Barcelona Central Food Market Organic Wastes : Experimental Study,” Bioresour. Technol., vol. 39, pp. 39-48, 1992.

[22] H. Bouallagui, O. Haouari, Y. Touhami, R. Ben Cheikh, L. Marouani, and M. Hamdi, "Effect of temperature on the performance of an anaerobic tubular reactor treating fruit and vegetable waste,” Process Biochem., vol. 39, pp. 2143-2148, 2004.

[23] K. J. Chae, A. Jang, S. K. Yim, and I. S. Kim, "The effects of digestion temperature and temperature shock on the biogas yields from the mesophilic anaerobic digestion of swine manure.,” Bioresour. Technol., vol. 99, no. 1, pp. 1-6, Jan. 2008.

[24] D. A. Ratkowsky, J. Olley, T. A. Mcmeekin, and A. Ball, "Relationship between temperature and growth rate of bacterial cultures .,” J. Bacteriol., vol. 149, no. 1, pp. 1-5, 1982.

[25] R. C. McKellar and X. Lu, Modeling Microbial Responses in Food. 2004.

[26] M. H. Zwietering, J. C. De Wit, and S. Notermans, "Application of predictive microbiology to estimate the number of Bacillus cereus in pasteurised milk at the point of consumption,” Int. J. Food Microbiol., vol. 30, pp. 55-70, 1996.

[27] H. S. Kwatra, "Performance of a solar still: Predicted effect of enhanced evaporation area on yield and evaporation temperature," Sol. Energy, vol. 56, no. 3, pp. 261-266, Mar. 1996.

[28] J. Holman, Heat Transfer, 10th ed. McGraw-Hill Education, 2009.

[29] J. A. Duffie and W. A. Beckman, "Solar engineering of thermal processes," 2013.

[30] D. M. Fairs and A. Ahmed, "USB Data Acquisition Using Peripheral Interface Control Microcontroller,” Tikrit J. Eng. Sci., vol. 20, no. 3, pp. 10-21, 2013.

[31] Y. Pérez-moret, “Implementación de Comunicación USB con Microcontrolador PIC18F4550 y LabVIEW,” 2012.

[32] N. E. KPATA-KONAN, K. F. KONAN, M. KOUAME KOUAME, Y. F. KOUAME, T. GNAGNE, and K. TANO, "Optimisation de la biométhanisation des effluents de manioc issus de la filière de fabrication de l’attiéké (semoule de manioc),” Int. J. Biol. Chem. Sci., vol. 5, no. 6, pp. 2330-2342, 2011.

[33] W. J. Gao, K. T. Leung, W. S. Qin, and B. Q. Liao, "Effects of temperature and temperature shock on the performance and microbial community structure of a submerged anaerobic membrane bioreactor,” Bioresour. Technol., vol. 102, pp. 8733-8740, 2011.

[34] J. H. Ahn and C. F. Forster, "The effect of temperature variations on the performance of mesophilic and thermophilic anaerobic filters treating a simulated papermill wastewater,” Process Biochem., vol. 37, pp. 589-594, 2002.

[35] S. Igoud, I. Tou, S. Kehal, A. Mansouri, and N. Touzi, "Première Approche de la Caractérisation du Biogaz Produit à Partir des Déjections Bovines,” vol. 5, pp. 123-128, 2002. 